\title{
Knowledge sharing activities among public sector employees: Evidence from Indonesia
}

\author{
Metha Djuwita Supriatna ${ }^{1 *}$ \\ ${ }^{1}$ Department of Apparatus Human Resources Management, STIA LAN Bandung \\ Polytechnic, Bandung, Indonesia \\ *Corresponding Author(s) Email: methadjuwita@gmail.com
}

\begin{abstract}
Knowledge sharing has an important role in the management of any organization. It can lead to increased knowledge creation, collaboration level, and level of innovation, which, in turn, increases organizational performances. However, few studies have empirically examined the effect of knowledge sharing activities on an individual's belief in a public sector organizational setting, especially in Indonesia. This study was conducted to analyze the role of knowledge sharing in affecting the activities of creative self-efficacy within public organizations. This study used purposive sampling which designed to focus on employees who have positioned as a researcher in one of Directorate of Ministry of Public Works and Housing of the Republic of Indonesia. The questionnaire used in this study was adapted from Brockhus and $\mathrm{Yu}$ instruments. The result of this study shows that there is a positive and significant effect of knowledge sharing activities on creative self-efficacy. The higher the level of knowledge sharing activities within the organization, the more it will encourage creative selfefficacy. The majority of the respondent in this study that classified as Y generation (Millenials) was the main reason of the differences between the conclusion of this study and previous ones who argues that knowledge sharing initiatives are more difficult to be implemented in public sector organization as many of public sector officers believe that the activities of knowledge sharing meant losing power and an extra work surface.
\end{abstract}

Keywords: Creative Self-Efficacy; Individual Beliefs; Knowledge Sharing; Millenial; Public Sector
JEL Code:

D23, D73, L22, L23

DOI:

10.31106/jema.v17i2.6686

Article History:

Received 2020/04/17

Reviewed 2020/06/03

Revised 2020/06/11

Accepted 2020/11/03

Licensed:

CC-BY 


\section{Introduction}

The concept of knowledge management explains the importance of managing the knowledge properly in organizations knowing that knowledge is valued as an important intellectual asset for the organization. The knowledge that needs to be managed by the organization is tacit and explicit knowledge which comes from individual employees then utilized as organizational knowledge. Awareness of the importance of knowledge as a strategic asset will motivate the organization, both public and private organizations, to improve their knowledge through management practices (Ahbabi et al., 2017). The idea of practicing knowledge management is following the integrated knowledge management cycle developed by Koenig (2011). The first phase in the knowledge management cycle is how captured the knowledge from individuals or groups within the organization. The next phase is to share the captured knowledge with individuals or groups in the organization (knowledge sharing). The final stage in this phase is to summarize the value and the effect of the shared knowledge to be applied in the organization. Ibrahim \& Heng (2017) and Tung (2018) added that a recent study found that knowledge sharing has an important role and tends to be the core of competence in knowledge management in achieving competitive advantage.

Knowledge sharing in organizations can be done either by individuals or groups. The practice of knowledge sharing in organizations is considered to be able to encourage innovation, organizational learning, and the development of the skills and abilities of individual employees, and ultimately can increase organizational productivity (Islam et al., 2018). The culture in sharing knowledge within the organization is important in avoiding the loss of knowledge or the accumulation of knowledge in one employee (Becker \& Zirpoli, 2017). Knowledge loss can occur if the only employee who has certain knowledge leaves the organization. While the accumulation of knowledge occurs if there are employees who don't want to share the knowledge, which can occur due to several things, such as the absence of rewards, or even don't want other people to understand more than themselves. Regarding the challenges in implementing knowledge sharing activities in different sector such as the private and public sector, Amayah (2013) argues that knowledge sharing initiatives are more difficult to be implemented in public sector organizations. The fear of losing control/power (Park \& Gabbard, 2018), the anxiety of losing promotion (Donnelly, 2019), less incentive for efficiency, the complexity of organization goals (Amayah, 2013), trust and leadership (Seba et al., 2012; Alsharo et al., 2017), bureaucratic culture (Wulf \& Butel, 2016; Hendryadi et al., 2019), and extra-works perception (Yao et al., 2007; Afshar Jalili \& Salemipour, 2019) is the 
several reasons of why public sector officers tend to resist to build a knowledge-sharing culture. Besides that reason, an individual issue such as personality traits (Agyemang et al., 2016; Borges et al., 2019), motivational factors (Andreeva \& Sergeeva, 2016; Nguyen et al., 2019), creative self-efficacy (Wu et al., 2012; Teng et al., 2019) also considered to influences the adoption of knowledge sharing. Puente-Díaz (2016) added that not only that creativity has highly correlated with the level of innovation, creativity also play important role in helping an organization achieving the outcomes target.

Prior creative self-efficacy study has focused on the relationships between individual attributes and innovation behavior. However, few studies have empirically examined the effect of knowledge sharing activities in a public sector organizational setting on an individual's belief, especially in Indonesia. Therefore, this study aims to analyze the effect of the activities of knowledge sharing within public organizations towards creative self-efficacy.

\section{Literature Review}

\section{Creative Self-Efficacy}

In social cognitive theory, Cabrera et al. (2006) argue that a person's behavior is governed extensively by the exercise of self-influence that is sustainable, or what is known as self-efficacy. Hardaningtyas (2020) defined self-efficacy as individual beliefs and confidence in his/her ability to execute and finish the task. Self-efficacy concerns a person's belief in his ability to control their level of function and all the experiences that affect their lives. In conclusion, self-efficacy is considered a more central and widespread mechanism of selfregulation (Naotunna \& Zhou, 2018). Furthermore, Pradesa et al. (2019) added that the more confident employees about their ability to do a task, the more dedicated they become to their jobs.

Tierney \& Farmer (2011) then develops the concept of creative self-efficacy which is rooted in the concept of self-efficacy. Creative self-efficacy relates to a series of results that provide benefits, including the development and implementation of ideas (Newman et al., 2018). Creative self-efficacy is based on employee confidence in solving problems in innovative ways. In the process of innovation, there are many obstacles to be handled, so psychological capital is needed to deal with uncertainty and failure (Hu \& Zhao, 2016). Creative self-efficacy has a role in innovation by increasing self-confidence, where someone considers their ability to complete the tasks and activities by this process (Hsu et al., 2011). Thus, confidence in the ability of creative thinking is the essence of creative performance which in turn allows the individual to face the challenge of effectively and efficiently 
(Alotaibi, 2016). Employees with high creative self-efficacy make them strong and persistent in achieving creative targets amidst the difficulties faced, even creative self-efficacy is found as a variable that can foster creativity (Gong et al., 2009).

\section{Knowledge Sharing}

The concept of knowledge classifies knowledge into two categories, tacit and explicit. Explicit knowledge is the knowledge that has been codified, documented. While tacit knowledge is the knowledge that is in the minds of humans, which will only be in someone's mind until someone else asks. Between these two forms of knowledge, tacit knowledge is valued as more knowledge than explicit knowledge, and it is important to capture and serve as organizational knowledge. Polanyi (1966) also believes that all knowledge is rooted in tacit knowledge. Knowledge sharing is in the second stage of the knowledge management cycle which is between the capture and application of important knowledge. Knowledge sharing involves the exchange of knowledge, experience, skills between employees through socialization, interaction, and training (Ibrahim \& Heng, 2017). Lin (2007) defined knowledge sharing as the efforts to transform individual knowledge within an organization to enhance business performances. Furthermore, Knowledge sharing is defined as a process of interaction/social activity, which allows members in the organization to acquire tacit and explicit knowledge with each other, so that there is a transfer of knowledge from the source of knowledge to the recipient of knowledge (Koenig, 2011; Malik \& Kanwal, 2018). As employees become increasingly involved in knowledge sharing, they will internalize a greater amount of knowledge (Yu et al., 2013). Knowledge sharing allows a variety of important things to happen, such as the creation of new knowledge (Veer Ramjeawon \& Rowley, 2017), work efficiency (Ali \& Yusof, 2004; Dwivedi et al., 2020), increasing the level of innovation (Huang \& Li, 2009; Markovic \& Bagherzadeh, 2018), and reduce unnecessary efforts (Monica Hu et al., 2009).

The practice of sharing knowledge can avoid the occurrence of 'corporate amnesia', which is caused by the loss of knowledge possessed by the organization, for example, due to the release of people who have certain knowledge from the organization and have not had time to share it with others. Bock et al. (2005) stated that there are several factors which are considered to encourage knowledge-sharing accordingly, (1) the existence of individual benefits, related to individual interests and getting personal interests, (2) the existence of group benefits, such as sharing behavior, relationships with others, and related to community interests, (3) the existence of organizational benefits, i.e. organization and increase 
organizational commitment. Furthermore, Koenig (2011) added that management support, technology, and organizational culture has a significant impact on knowledge sharing.

\section{The Relationship Between Knowledge Sharing and Creative Self-Efficacy}

Although Amayah (2013) argues that knowledge sharing initiatives are more difficult to be implemented in public sector organization due to several reasons such as the fear of losing control/power (Park \& Gabbard, 2018), the anxiety of losing promotion (Liebowitz \& Megbolugbe, 2003; Donnelly, 2019), trust and leadership (Seba et al., 2012; Alsharo et al., 2017), bureaucratic culture (Wulf \& Butel, 2016; Hendryadi et al., 2019), and extra-works perception (Yao et al., 2007; Afshar Jalili \& Salemipour, 2019). A previous study from Hu \& Zhao (2016) has a clear conclusion that there was a significant link between knowledge sharing and creative self-efficacy. Therefore, the hypotheses in this study are formulated as follows.

$\mathrm{H}_{1}$ : There is a significant relationship between knowledge sharing and creative selfefficacy within public sector organizations.

\section{Methods}

The study design employed in this study was mainly descriptive. A survey-based methodology was employed through a five-point Likert scale questionnaire to elicit the effect of knowledge sharing activities on creative self-efficacy. This study used purposive sampling which designed to focus on employees who have positioned as a researcher in one of the Directorate of the Ministry of Public Works and Housing of the Republic of Indonesia, with total respondents were 94 researchers.

Figure 1. Research Framework

Knowledge Sharing (KS) $\longrightarrow$ Creative Self-Efficacy (CSE)

The fifteen instruments of Brockhus et al. (2014) were used to measured creative selfefficacy. While to measure knowledge sharing, the six instruments of Yu et al. (2013) were used in this study. Table 1 shows detailed information about the item of this study. Then, to check the validity and reliability of instruments, the value of the Pearson Correlation and Cronbach's Alpha was employed as the parameter criterion. Regression analysis was used in this study to test the effect of knowledge sharing activities on creative self-efficacy. Table 2 shows the detailed information about validity and reliability results. The instrument item is declared valid and reliable when the counted value (Pearson Correlation and Cronbach's 
Alpha) is more than 0.300 and 0.600 . Therefore, based on the description of Table 2, it can be concluded that all item measured in this study is valid and reliable.

Table 1. Variable and Item

\begin{tabular}{|c|c|c|c|}
\hline Variable & Code & Item & Reference \\
\hline \multirow{14}{*}{$\begin{array}{l}\text { Creative Self- } \\
\text { Efficacy } \\
(\mathrm{CSE})\end{array}$} & CSE1 & I am not afraid to express my ideas & \multirow{21}{*}{$\begin{array}{l}\text { Brockhus et al. } \\
\quad \text { (2014) }\end{array}$} \\
\hline & CSE2 & I have a positive self-image & \\
\hline & CSE3 & $\begin{array}{l}\text { I am confident that I could deal with unexpected } \\
\text { events }\end{array}$ & \\
\hline & CSE4 & $\begin{array}{l}\text { I feel very confident with my ability to compete } \\
\text { with others to do the task }\end{array}$ & \\
\hline & CSE5 & I consider myself to be innovative & \\
\hline & CSE6 & I am a creative person & \\
\hline & CSE7 & I can solve problems efficiently & \\
\hline & CSE8 & I trust my creative abilities & \\
\hline & CSE9 & Compared to my friends, my ideas are outstanding & \\
\hline & CSE10 & $\begin{array}{l}\text { I proved that I can find at least one solution for } \\
\text { any difficult situation }\end{array}$ & \\
\hline & CSE11 & I can handle tasks that require creative thinking & \\
\hline & CSE12 & $\begin{array}{l}\text { I am good at proposing "out of the box" } \\
\text { solutions }\end{array}$ & \\
\hline & CSE13 & $\begin{array}{l}\text { I am confident I can develop creative ideas for } \\
\text { almost any problem }\end{array}$ & \\
\hline & CSE14 & $\begin{array}{l}\text { Whenever difficulties come, I usually find several } \\
\text { solutions }\end{array}$ & \\
\hline \multirow{7}{*}{$\begin{array}{l}\text { Knowledge } \\
\text { Sharing (KS) }\end{array}$} & CSE15 & I don't consider myself as creative $(\mathrm{R})$ & \\
\hline & KS1 & I often help my coworkers to communicate better & \\
\hline & $\mathrm{KS} 2$ & $\begin{array}{l}\text { I often encourage colleagues to bring up good } \\
\text { ideas and suggestions so it can enhance the overall } \\
\text { service standards at work }\end{array}$ & \\
\hline & $\mathrm{KS} 3$ & I often help colleagues with problem-solving & \\
\hline & KS4 & $\begin{array}{l}\text { I will take action to help whenever my colleagues } \\
\text { face difficulty }\end{array}$ & \\
\hline & KS5 & $\begin{array}{l}\text { I will demonstrate how to do something when } \\
\text { things are difficult to explain }\end{array}$ & \\
\hline & KS6 & $\begin{array}{l}\text { When I am preparing a document, I am willing to } \\
\text { write down what I know for my colleagues to refer } \\
\text { to }\end{array}$ & \\
\hline
\end{tabular}


Table 2. Validity and Reliability Result

\begin{tabular}{|c|c|c|c|c|c|}
\hline Variable/Item & $\begin{array}{c}\text { Pearson } \\
\text { Correlation }\end{array}$ & Criteria & $\begin{array}{c}\text { Cronbach's } \\
\text { Alpha }\end{array}$ & Criteria & Decision \\
\hline CSE & & & 0.926 & $>0.600$ & Reliable \\
\hline CSE1 & 0.558 & $>0.300$ & & & Valid \\
\hline CSE2 & 0.474 & $>0.300$ & & & Valid \\
\hline CSE3 & 0.569 & $>0.300$ & & & Valid \\
\hline CSE4 & 0.634 & $>0.300$ & & & Valid \\
\hline CSE5 & 0.837 & $>0.300$ & & & Valid \\
\hline CSE6 & 0.910 & $>0.300$ & & & Valid \\
\hline CSE7 & 0.578 & $>0.300$ & & & Valid \\
\hline CSE8 & 0.852 & $>0.300$ & & & Valid \\
\hline CSE9 & 0.717 & $>0.300$ & & & Valid \\
\hline CSE10 & 0.776 & $>0.300$ & & & Valid \\
\hline CSE11 & 0.896 & $>0.300$ & & & Valid \\
\hline CSE12 & 0.793 & $>0.300$ & & & Valid \\
\hline CSE13 & 0.748 & $>0.300$ & & & Valid \\
\hline CSE14 & 0.590 & $>0.300$ & & & Valid \\
\hline CSE15 & 0.611 & $>0.300$ & & & Valid \\
\hline KS & & & 0.860 & $>0.600$ & Reliable \\
\hline $\mathrm{KS} 1$ & 0.689 & $>0.300$ & & & Valid \\
\hline $\mathrm{KS} 2$ & 0.748 & $>0.300$ & & & Valid \\
\hline $\mathrm{KS} 3$ & 0.863 & $>0.300$ & & & Valid \\
\hline KS4 & 0.870 & $>0.300$ & & & Valid \\
\hline KS5 & 0.786 & $>0.300$ & & & Valid \\
\hline KS6 & 0.676 & $>0.300$ & & & Valid \\
\hline
\end{tabular}

\section{Result and Discussion}

The respondent in this study reflected the age of the general public sector in Indonesia which mainly consist of $\mathrm{X}$ generation (born 1965-1979) were 29\% and $\mathrm{Y}$ generation/millennials (born 1980-2001) were 71\%. While the majority of the respondent in 
this study can be described as male (71\%) with most of them hold Master Degree education $(83 \%)$.

Table 3. Hypotheses Testing

\begin{tabular}{lccccc}
\hline Hypotheses & t-Value & $\begin{array}{c}\text { t-Table } \\
\text { Criteria }\end{array}$ & Sig. & $\begin{array}{c}\text { Sig. } \\
\text { Criteria }\end{array}$ & Decision \\
\hline $\mathrm{H}_{1} \mathrm{KS}->\mathrm{CSE}$ & 5.458 & $>1.687$ & 0.000 & $<0.005$ & Accepted \\
\hline
\end{tabular}

An independent sample t-test was employed in this study to test the proposed hypotheses whether knowledge sharing influences creative self-efficacy. Table 3 shows that the value of t-tested was 5.458 (which is higher than the value of t-statistics 1.687) with a significant value of 0.000 (which is lower than the significances criteria of 0.05). Therefore, it can be concluded that $\mathrm{H}_{1}$ of this study was accepted, which means that there is a positive and significant relationship between knowledge sharing (KS) and creative self-efficacy (CSE). The higher the level of knowledge sharing activities within the organization, the more it will encourage creative self-efficacy.

This result of this study supports a previous study conducted by Hu \& Zhao (2016) that stated that there was a significant effect between knowledge sharing and creative selfefficacy. The majority of the respondent in this study that classified as $\mathrm{Y}$ generation (Millenials) was the main reason of the differences between the conclusion of this study and previous ones who argues that knowledge sharing initiatives are more difficult to be implemented in public sector organization as many of public sector officers believe that the activities of knowledge sharing meant losing power and an extra work surface. McHenry \& Ash (2013) support the argument by stating that rather than $\mathrm{X}$ generation that likely to be more worried about competition, potential job loss, and the lack of incentives to share, $\mathrm{Y}$ generation (Millenials) are more adaptive to challenges and cultural differences, didn't like to plan for long periods, multitasking, open-minded, needy for feedback, and easy to collaborate (Bencsik et al., 2016).

The nature of respondents in this study that classified as researchers also considered having an important role in affecting the knowledge sharing on creative self-efficacy. A qualified researcher should be open minded and have a willingness to share knowledge with their co-researcher to produce a better result of research. Tang \& Kaufman (2017) and Srikoon et al. (2018) added that the creativity of thinking (uniqueness) was one of the personal characteristics of researchers that can enhance self-perceived creativity and creative motivation. The level of creative self-efficacy can increase significantly by implementing 
knowledge sharing. A previous study from Jen et al. (2020) and $\mathrm{Hu}$ et al. (2020) concluded that the activities of knowledge sharing like mentoring and collaboration prove significantly can enhance the level of creative confidence of employees.

\section{Conclusion and Suggestion}

Unlike, the prior study that claims that knowledge sharing activities are rarely to be found in public sector organizations rather than in private sectors due to several reasons. The result of this study concluded the opposite. There is a positive and significant relationship between knowledge sharing (KS) and creative self-efficacy (CSE) within a public organizational setting. The activities of knowledge sharing like mentoring and collaboration prove significantly affect the level of creative self-efficacy of public sector officers which means that the higher the level of knowledge sharing activities within the organization, the more it will encourage creative self-efficacy. The majority of the respondent in this study that classified as $\mathrm{Y}$ generation (millennial) considered as the main reason of the differences between the conclusion of this study and previous ones who argues that there are many of public sector officers believes that the activities of knowledge sharing will cause them negative impact such as losing power, losing an opportunity, and an extra work surface. Also, the respondent criterion of this study that classified as researchers affect the relationship of knowledge sharing toward creative self-efficacy as they have to be compelled to do knowledge sharing activities and collaborate with their co-researcher to produce the better result of research.

\section{References}

Afshar Jalili, Y., \& Salemipour, F. (2019). Group organizational citizenship behavior and knowledge sharing. VINE Journal of Information and Knowledge Management Systems, 50(1), 117-135. https://doi.org/10.1108/VJIKMS-12-2018-0117

Agyemang, F. G., Dzandu, M. D., \& Boateng, H. (2016). Knowledge sharing among teachers: the role of the Big Five Personality traits. VINE Journal of Information and Knowledge Management Systems, 46(1), 64-84. https://doi.org/10.1108/VJIKMS-122014-0066

Ahbabi, S. Al, Singh, S. K., Gaur, S. S., \& Balasubramanian, S. (2017). A knowledge management framework for enhancing public sector performance. International Journal $\begin{array}{llll}\text { of Knowledge } \quad \text { Management } & \text { Studies, } & \text { 8(3/4), }\end{array}$ https://doi.org/10.1504/IJKMS.2017.087076 
Ali, H. M., \& Yusof, Z. M. (2004). Knowledge management in Malaysian banks: A study of causes and effects. Information Development, 20(3), 161-168. https://doi.org/10.1177/0266666904046819

Alotaibi, K. N. (2016). Psychometric properties of creative self-efficacy inventory among distinguished students in Saudi Arabian universities. Psychological Reports, 118(3), 902-917. https://doi.org/10.1177/0033294116646021

Alsharo, M., Gregg, D., \& Ramirez, R. (2017). Virtual team effectiveness: The role of knowledge sharing and trust. Information \& Management, 54(4), 479-490. https://doi.org/10.1016/j.im.2016.10.005

Amayah, A. T. (2013). Determinants of knowledge sharing in a public sector organization. Journal of Knowledge Management, 17(3), 454-471. https://doi.org/10.1108/JKM-112012-0369

Andreeva, T., \& Sergeeva, A. (2016). The more the better ... or is it? The contradictory effects of HR practices on knowledge-sharing motivation and behaviour. Human Resource Management Journal, 26(2), 151-171. https://doi.org/10.1111/17488583.12100

Becker, M. C., \& Zirpoli, F. (2017). How to avoid innovation competence loss in R\&D outsourcing. California Management Review, 59(2), 24-44. https://doi.org/10.1177/0008125617697941

Bencsik, A., Juhász, T., \& Horváth-Csikós, G. (2016). Y and Z generations at workplaces. Journal of Competitiveness, 6(3), 90-106. https://doi.org/10.7441/joc.2016.03.06

Bock, Zmud, Kim, \& Lee. (2005). Behavioral intention formation in knowledge sharing: Examining the roles of extrinsic motivators, social-psychological forces, and organizational climate. MIS Quarterly, 29(1), 87. https://doi.org/10.2307/25148669

Borges, R., Bernardi, M., \& Petrin, R. (2019). Cross-country findings on tacit knowledge sharing: evidence from the Brazilian and Indonesian IT workers. Journal of Knowledge Management, 23(4), 742-762. https://doi.org/10.1108/JKM-04-2018-0234

Brockhus, S., Van der Kolk, T. E. C., Koeman, B., \& Badke-Schaub, P. G. (2014). The influence of creative self-efficacy on creative performance. In Proceedings of the DESIGN 2014 13th International Design Conference.

Cabrera, Á., Collins, W. C., \& Salgado, J. F. (2006). Determinants of individual engagement in knowledge sharing. The International Journal of Human Resource Management, 17(2), 245-264. https://doi.org/10.1080/09585190500404614

Donnelly, R. (2019). Aligning knowledge sharing interventions with the promotion of firm 
success: The need for SHRM to balance tensions and challenges. Journal of Business Research, 94, 344-352. https://doi.org/10.1016/j.jbusres.2018.02.007

Dwivedi, P., Chaturvedi, V., \& Vashist, J. K. (2020). Transformational leadership and employee efficiency: knowledge sharing as mediator. Benchmarking: An International Journal, 27(4), 1571-1590. https://doi.org/10.1108/BIJ-08-2019-0356

Gong, Y., Huang, J.-C., \& Farh, J.-L. (2009). Employee learning orientation, transformational leadership, and employee creativity: The mediating role of employee creative self-efficacy. Academy of Management Journal, 52(4), 765-778. https://doi.org/10.5465/amj.2009.43670890

Hardaningtyas, R. T. (2020). Personal resources and turnover intention among private sector employees: Does work engagement still matter? JEMA: Jurnal Ilmiah Bidang Akuntansi Dan Manajemen, 17(1), 1. https://doi.org/10.31106/jema.v17i1.4989

Hendryadi, Suratna, Suryani, \& Purwanto, B. (2019). Bureaucratic culture, empowering leadership, affective commitment, and knowledge sharing behavior in Indonesian government public services. Cogent Business \& Management, 6(1). https://doi.org/10.1080/23311975.2019.1680099

Hsu, L. A. M., Hou, S.-T., \& Fan, H.-L. (2011). Creative self-efficacy and innovative behavior in a service setting: Optimism as a moderator. The Journal of Creative Behavior, 45(4), 258-272. https://doi.org/10.1002/j.2162-6057.2011.tb01430.x

$\mathrm{Hu}$, B., \& Zhao, Y. (2016). Creative self-efficacy mediates the relationship between knowledge sharing and employee innovation. Social Behavior and Personality: An International Journal, 44(5), 815-826. https://doi.org/10.2224/sbp.2016.44.5.815

Hu, C., Baranik, L. E., Cheng, Y., Huang, J., \& Yang, C. (2020). Mentoring support and protégé creativity: examining the moderating roles of job dissatisfaction and Chinese traditionality. Asia Pacific Journal of Human Resources, 58(3), 335-355. https://doi.org/10.1111/1744-7941.12226

Huang, J., \& Li, Y. (2009). The mediating effect of knowledge management on social interaction and innovation performance. International Journal of Manpower, 30(3), 285-301. https://doi.org/10.1108/01437720910956772

Ibrahim, S., \& Heng, L. H. (2017). The effect of individual motivational factors towards knowledge sharing at small and medium enterprises. International Journal of $\begin{array}{llll}\text { Knowledge } \quad \text { Management } & \text { Studies, }\end{array}$ https://doi.org/10.1504/IJKMS.2017.087068

Islam, M. A., Jantan, A. H., Khan, A. M., Rahman, M. H., \& Monshi, O. (2018). Impact of 
motivational factors on knowledge sharing behaviour of managers in Ready Made Garments (RMG) Industry of Bangladesh. Journal of Business and Retail Management Research (JBRMR), 13(1). Retrieved from https://ssrn.com/abstract=3419439

Jen, C. T., Hu, J., Zheng, J., \& Xiao, L. L. (2020). The impacts of corporate governance mechanisms on knowledge sharing and supply chain performance. International Journal of Logistics Research and Applications, 23(4), 337-353. https://doi.org/10.1080/13675567.2019.1691515

Koenig, M. E. . (2011). Knowledge Management in Theory and Practice. Journal of the American Society for Information Science and Technology, 62(10), 2083-2083. https://doi.org/10.1002/asi.21613

Liebowitz, J., \& Megbolugbe, I. (2003). A set of frameworks to aid the project manager in conceptualizing and implementing knowledge management initiatives. International Journal of Project Management, 21(3), 189-198. https://doi.org/10.1016/S02637863(02)00093-5

Lin, C. (2007). To share or not to share: modeling knowledge sharing using exchange ideology as a moderator. Personnel Review, 36(3), 457-475. https://doi.org/10.1108/00483480710731374

Malik, M. S., \& Kanwal, M. (2018). Impacts of organizational knowledge sharing practices on employees' job satisfaction. Journal of Workplace Learning, 30(1), 2-17. https://doi.org/10.1108/JWL-05-2016-0044

Markovic, S., \& Bagherzadeh, M. (2018). How does breadth of external stakeholder cocreation influence innovation performance? Analyzing the mediating roles of knowledge sharing and product innovation. Journal of Business Research, 88, 173-186. https://doi.org/10.1016/j.jbusres.2018.03.028

McHenry, W. K., \& Ash, S. R. (2013). Knowledge management and collaboration: Generation x vs. generation Y. International Journal of Business and Social Science, $4(12)$.

Monica Hu, M.-L., Horng, J.-S., \& Christine Sun, Y.-H. (2009). Hospitality teams: Knowledge sharing and service innovation performance. Tourism Management, 30(1), 41-50. https://doi.org/10.1016/j.tourman.2008.04.009

Naotunna, S., \& Zhou, E. (2018). Autonomy and creativity of professional teleworkers: the mediating role of creative self-efficacy. International Journal of Organizational Innovation, 10(3), 300-307.

Newman, A., Tse, H. H. M., Schwarz, G., \& Nielsen, I. (2018). The effects of employees' 
creative self-efficacy on innovative behavior: The role of entrepreneurial leadership. Journal of Business Research, 89, 1-9. https://doi.org/10.1016/j.jbusres.2018.04.001

Nguyen, T.-M., Nham, T. P., Froese, F. J., \& Malik, A. (2019). Motivation and knowledge sharing: A meta-analysis of main and moderating effects. Journal of Knowledge Management, 23(5), 998-1016. https://doi.org/10.1108/JKM-01-2019-0029

Park, J., \& Gabbard, J. L. (2018). Factors that affect scientists' knowledge sharing behavior in health and life sciences research communities: Differences between explicit and implicit knowledge. Computers in Human Behavior, 78, 326-335. https://doi.org/10.1016/j.chb.2017.09.017

Polanyi, M. (1966). The logic of tacit inference. Philosophy, 41(155), 1-18. https://doi.org/10.1017/S0031819100066110

Pradesa, H. A., Dawud, J., \& Affandi, M. N. (2019). Mediating role of affective commitment in the effect of ethical work Climate on felt obligation among public officers. JEMA: Jurnal Ilmiah Bidang Akuntansi Dan Manajemen, 16(2), 133. https://doi.org/10.31106/jema.v16i2.2707

Puente-Díaz, R. (2016). Creative self-efficacy: An exploration of its antecedents, consequences, and applied implications. The Journal of Psychology, 150(2), 175-195. https://doi.org/10.1080/00223980.2015.1051498

Seba, I., Rowley, J., \& Lambert, S. (2012). Factors affecting attitudes and intentions towards knowledge sharing in the Dubai Police Force. International Journal of Information Management, 32(4), 372-380. https://doi.org/10.1016/j.ijinfomgt.2011.12.003

Srikoon, S., Bunterm, T., Nethanomsak, T., \& Tang, K. N. (2018). Effect of 5P model on academic achievement, creative thinking, and research characteristics. Kasetsart Journal of Social Sciences, 39(3), 488-495. https://doi.org/10.1016/j.kjss.2018.06.011

Tang, C., \& Kaufman, J. C. (2017). Personal characteristics that distinguish creative scientists from less creative scientists. The Journal of Creative Behavior, 51(3), 204-215. https://doi.org/10.1002/jocb.99

Teng, C., Hu, C., \& Chang, J. (2019). Triggering creative self-efficacy to increase employee innovation behavior in the hospitality workplace. The Journal of Creative Behavior, jocb.419. https://doi.org/10.1002/jocb.419

Tierney, P., \& Farmer, S. M. (2011). Creative self-efficacy development and creative performance over time. Journal of Applied Psychology, 96(2), 277-293. https://doi.org/10.1037/a0020952

Tung, K. Y. (2018). Memahami knowledge management. Jakarta: PT. Indeks. 
Veer Ramjeawon, P., \& Rowley, J. (2017). Knowledge management in higher education institutions: enablers and barriers in Mauritius. The Learning Organization, 24(5), 366377. https://doi.org/10.1108/TLO-03-2017-0030

Wu, C., Lee, C., \& Tsai, L. (2012). Influence of creativity and knowledge sharing on performance. Journal of Technology Management in China, 7(1), 64-77. https://doi.org/10.1108/17468771211207358

Wulf, A., \& Butel, L. (2016). Knowledge sharing and innovative corporate strategies in collaborative relationships: The potential of open strategy in business ecosystems (pp. 165-181). https://doi.org/10.1007/978-3-319-32877-5_13

Yao, L. J., Kam, T. H. Y., \& Chan, S. H. (2007). Knowledge sharing in Asian public administration sector: the case of Hong Kong. Journal of Enterprise Information Management, 20(1), 51-69. https://doi.org/10.1108/17410390710717138

Yu, Y., Hao, J.-X., Dong, X.-Y., \& Khalifa, M. (2013). A multilevel model for effects of social capital and knowledge sharing in knowledge-intensive work teams. International Journal of Information Management, 33(5), 780-790. https://doi.org/10.1016/j.ijinfomgt.2013.05.005 